\title{
A novel conceptual model of intrusion related gold bearing systems and exploration tools
}

\author{
Eugen Orlandea ${ }^{1} \&$ Şerban-Nicolae Vlad ${ }^{2}$ \\ ${ }^{1}$ Ferdomin SpA, Calle Almirante Latorre, 151, 1530000, Copiapo, Atacama, Chile \\ ${ }^{2}$ Babeş-Bolyai University, Department of Geology, Kogălniceanu 1, 400084 Cluj-Napoca, Romania
}

Received: May 2019; accepted February 2020

Available online 11 February 2020

DOI: https://doi.org/10.5038/1937-8602.63.1.1304

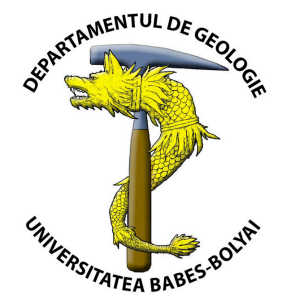

\begin{abstract}
Despite numerous debates conducted in the last two decades, the concept of intrusion related gold systems IRGS remains controversial and sometimes befuddling. The key issue drifts from case to case, i.e., initial to subsequent proposed classifications, presence of gold in reduced fluids-porphyritic environments, non-porphyry gold in orogenic terrains and participation of non-magmatic gold fluids in depositional processes. Trying to avoid atypical or particular aspects of certain deposits, a genuine metallogenetic depiction intends to enhance the intrusion related systems meaning. Gold is either a major constituent or a mere byproduct. A vertical metal zonation develops from surface to depth: $\mathrm{Au}, \mathrm{Ag} \rightarrow \mathrm{Cu}, \mathrm{Pb}, \mathrm{Zn} \rightarrow \mathrm{Cu}, \mathrm{Au} \rightarrow \mathrm{Cu}, \mathrm{Mo}(\mathrm{Au}), \mathrm{W} \rightarrow \mathrm{Fe}, \mathrm{Cu}, \mathrm{Au}(\mathrm{Co}, \mathrm{W}) \rightarrow \mathrm{U}, \mathrm{Ce}, \mathrm{La}$. Whether the relationship between different intrusion related occurrences is well known at shallow depth (epithermal, mesothermal, porphyry), so far less knowledge and understanding is assigned to deep seated mineralization (porphyry, Iron OxidesCopper-Gold/IOCG). A specific relationship between those two deep seated ore styles emerges, that is the IOCG, confined to magmatic-hydrothermal type, is situated in the root zone of a deep porphyry system. Complementary information about updated classic exploration tools encompasses specifically geochemical association, geophysical signature, key alteration minerals, $\mathrm{Au} / \mathrm{Ag}$ ratio and, last but not least, type minerals that contain/include gold in each intrusion related environment. A further valuable tool is given by the estimate of Au grade range specific to each gold bearing mineral sample in shallow or deep seated setting.
\end{abstract}

Keywords: gold, intrusion related deposits, conceptual model, metal zoning, exploration tools.

\section{INTRODUCTION}

Recently defined Intrusion-Related Gold Systems (IRGS) are restrictively referring to reduced ore mineral assemblages characterized by lacking of regional copper, but known for their tungsten and tin geochemical signature with associated Bi-Te-As-Mo-Sb metal tenor (Sillitoe and Thompson, 1998; Thompson et al., 1999; Lang et al., 2000; Lang and Baker, 2001; Hart et al., 2002; Hart 2005). Early classification described gold-only porphyry deposits and seems to be confined to what is presented now as oxidized IRGS deposits from the Circum-Pacific Island Arc region. Controversial Australian deposits such as Kidston, Timbarra and Red Dome, Alaska deposits such as Fort Knox and Donlin Creak, as well as Dublin Gulch (Yukon, Canada) were included in the new class deposits model (Thompson and Newberry, 2000; Hart, 2005). Nevertheless, the IRGS, often occurring in continental setting, are distinct from those intrusion related gold deposits associated with calcophile-oxidized magmas and/or orogenic terrains (i.e., mostly porphyry copper style) formed in response of plates collide (Lang, 2001; Lowerstern, 2001; White, 2001).

High temperature-saline fluids are preserved in some intrusion related ore deposits, but the gold mineralization stage range from total magmatic to dominant magmatic fluids with variable amount of external brines, probably introduced into the geothermal system earlier by sediments assimilation or during later cooling (Barton and Johnson, 1996; Mustard, 2001, 2004; Muntean et al., 2011). Depending on the origin and delineated subtypes of intrusion related gold bearing deposits, felsic to intermediate I type or S type granitic magmas are involved (Mustard, 2001; Somarin and Ashley, 2004; Hart, 2005), but M type granitic magmas found in IOCG deposits are regularly ignored (Filip and Orlandea, 2015).

Most authors agree that magmas play a key role in IRGS genesis as a source of energy (temperature, pressure) as well as source of mineralized fluids. Whereas there is a general agreement that the intrusion is an important vehicle to transport heat into the shallow crust, by far the source of metals remains a more problematic issue (Corbett and Leach, 1997; Gammons and Williams-Jones, 1997; Sillitoe, 2000; Simmons et al., 2005).

Furthermore, whereas epithermal shallow depth ore formation involves large scale hydrothermal-meteoric convection cells (Sillitoe and Hedenquist, 2003), more complex ore-forming processes occur at deep seated levels. Oxidized-still preserved epithermal suite can be seen in the shallowest part of many IOCG deposits of Chile, associated with felsic to intermediate plutons. Additionally, some porphyry environments show a noteworthy gradual passing 
to more common IOCG features at depth, instead of early described overlapping (Carten, 1986; Wanheinen et al., 2003; Martinson and Virkkunen, 2004; Filip and Orlandea, 2016).

The modern exploration of IRGS is based on a variety of integrated advanced data and tools. Up to date geochemical techniques such as reduction-oxidation potential in soil or soil gas analysis (Kelley et al., 2006) and remote sensing infrared spectroscopy, e.g., Advanced Spaceborn Thermal Emission and Reflection (ASTER) are increasingly helpful for mapping the epithermal-porphyry environments in arid-semiarid terrains (Rowen and Mars, 2003). Also, the 3D routine inversion of potential field data (magnetic, gravimetric, electric) became a very useful geophysical method for new discoveries in the last decade (Coggon, 2004; Robert et al., 2007). Drillhole vectoring using downhole geological, geochemical and geophysics methods are increasingly important in achieving exploration success (Holliday and Cooke, 2007). Mineral mapping and lithogeochemistry became recently used to establish vectors to detect ore centers in porphyry systems (Dilles, 2012). That means tremendous progress in exploration. Consequently, geologists are nowadays more than ever equipped for new discoveries. Nevertheless, there is no any "supreme" technique for gold predictions beyond the geological features, therefore the longestablished field geological and geochemical methods and tools of classical exploration cannot be ignored. Always the best targets are located where a wide combination of anomaly types (geological/alteration, geochemical, geophysical) cluster, timely to be integrated-interpreted.

In order to avoid as much as possible existing, but still controversial classifications or models, the present paper promotes an integrated-simplified metallogenetic outline of the economic ore types wherein gold occur as major compound or as byproduct. The genetic-spatial position of each type (epithermal, mesothermal, skarn, porphyry, Carlin style, IOCG) is complemented with information regarding the metals aureole, key alteration minerals and ore anatomy, giving impetus to highlight new exploration tools. The footprints of different gold typologies are emphasized by vertical/lateral zoning, gold-host minerals and comprehensive mineralogicalpetrographic, geochemical, geophysical and exploration criteria. The new image refers both to extensional-rifting and convergent-plate collide or intraplate metallogenetic terrains, worldwide accepted settings of magmatic-hydrothermal ore deposits.

In respect of previous above mentioned ideas and because the role of non magmatic fluids in IOCG deposits is still a subject of actual controversial debates, this paper refers only to magmatic-hydrothermal IOCG mineralized environment.

\section{VERTICAL METAL-ALTERATION ZONATION AND KEY ELEMENTS OF GOLD BEARING- INTRUSION RELATED DEPOSITS}

Gold mineralization shows a larger variation of deposit styles than any other metal. Gold occurrence in magmatichydrothermal systems as major commodity or as byproduct is somehow connected with upper mantle-derived alkalirich magmas, although in some cases there is an indirect link to such magmas, that is just spatial association which predate/postdate the main gold bearing intrusion event. The genetic significance of the $\mathrm{K}-\mathrm{Na}$ rich fluids is emphasized both in shallow systems (epithermal, mesothermal, Carlin type) as well as in deeper systems (porphyry, skarn, IOCG). $\mathrm{M}$ type (mantle derived) parental granitoid magmas are already mentioned in gold-copper fields all over the world, e.g., Panaguna, Lihir in Papua-New Guinee (Clark, 1990; Moyle et al., 1990; Ronacher et al., 2004), Punta del Cobre district in Chile (Marschik and Fontbote, 2001; Filip and Orlandea, 2015) and Olympic Dam in Australia (Fraser et al., 2007).

A conceptual model based on most productive IRGS is exposed in Figure 1. The development scheme encloses the sediment-hosted Carlin type, based on nowadays accepted evidence of dominant magmatic-hydrothermal fluids and origin (Cline et al., 2005; Muntean et al., 2011). Furthermore, the IOCG group of ore deposits is linked for the first time in a fully developed intrusion related model, despite amounts of non-magmatic-external fluids involved in very specific geological settings (Ryan, 1998; Barton and Johnson, 2000; Filip and Orlandea, 2015). In contrast, the sediment hosted Witwatersrand type gold deposits that contain the second largest gold potential worldwide, is definitely considered as major auriferous paleo-placer. Recent works suggest that syngenetic to diagenetic sedimentary deposition of gold mineralization prevails over fluids of hydrothermal origin (Meier et al., 2009; Heinrich, 2015).

The proposed metal zonation is a ranking expression of major metals into the system, that start from the shallow $\mathrm{Au}-\mathrm{Ag}$ level, continues with $\mathrm{Pb}, \mathrm{Zn}, \mathrm{Cu}, \mathrm{Au}, \mathrm{Mo}, \mathrm{W}$ at intermediate depths and $\mathrm{Fe}, \mathrm{Cu}, \mathrm{Au},(\mathrm{Co}, \mathrm{W}), \mathrm{U}, \mathrm{Ce}, \mathrm{La}$ in deep seated standing. Vuggy quartz, alunite, adulariasericite and carbonate alteration minerals are important in gold bearing intrusion related epithermal mineralization. Garnet, pyroxene and wollastonite are characteristic for skarn deposits. Biotite is common alteration product of mesothermal to shallow porphyry systems, whereas potassic feldspar, albite, iron oxide, scapolite and actinolite are associated to deep seated porphyry-IOCG type environments. The key features of selected gold bearing-intrusion related ore deposits and their metallogenetic position enable to initiate new exploration tools/criteria to be applied by regional to large scale projects.

\section{Epithermal deposits}

Originally, epithermal deposits were defined by Lindgren (1922) as precious or base metal deposits forming at shallow depth and low temperature-pressure conditions. Recent data indicate that the most epithermal ores form at temperatures between $100^{\circ} \mathrm{C}$ and $300^{\circ} \mathrm{C}$ and depths up to $750-800 \mathrm{~m}$. Epithermal gold deposits were divided into high, intermediate and low sufidation subtypes (Hedenquist et al. ,2000; Sillitoe and Hedenquist, 2003), but the intermediate sulfidation seems to be rather a transitional term between high and low degree of system sulfidation closer to sulfide-poor style.

The high sulfidation deposits occur right above the feeder zone, commonly a porphyry intrusion, and associate with near paleosurface-highly oxidized fluids typical of acidic-hypogene solutions. Proximal vuggy silica and distal advanced argillic alteration (kaolinite, dickite, alunite) accompany commonly disseminated or massive-sulfide rich $(\mathrm{Pb}, \mathrm{Zn}$, and $\mathrm{Cu})$ gold bearing mineralization. 


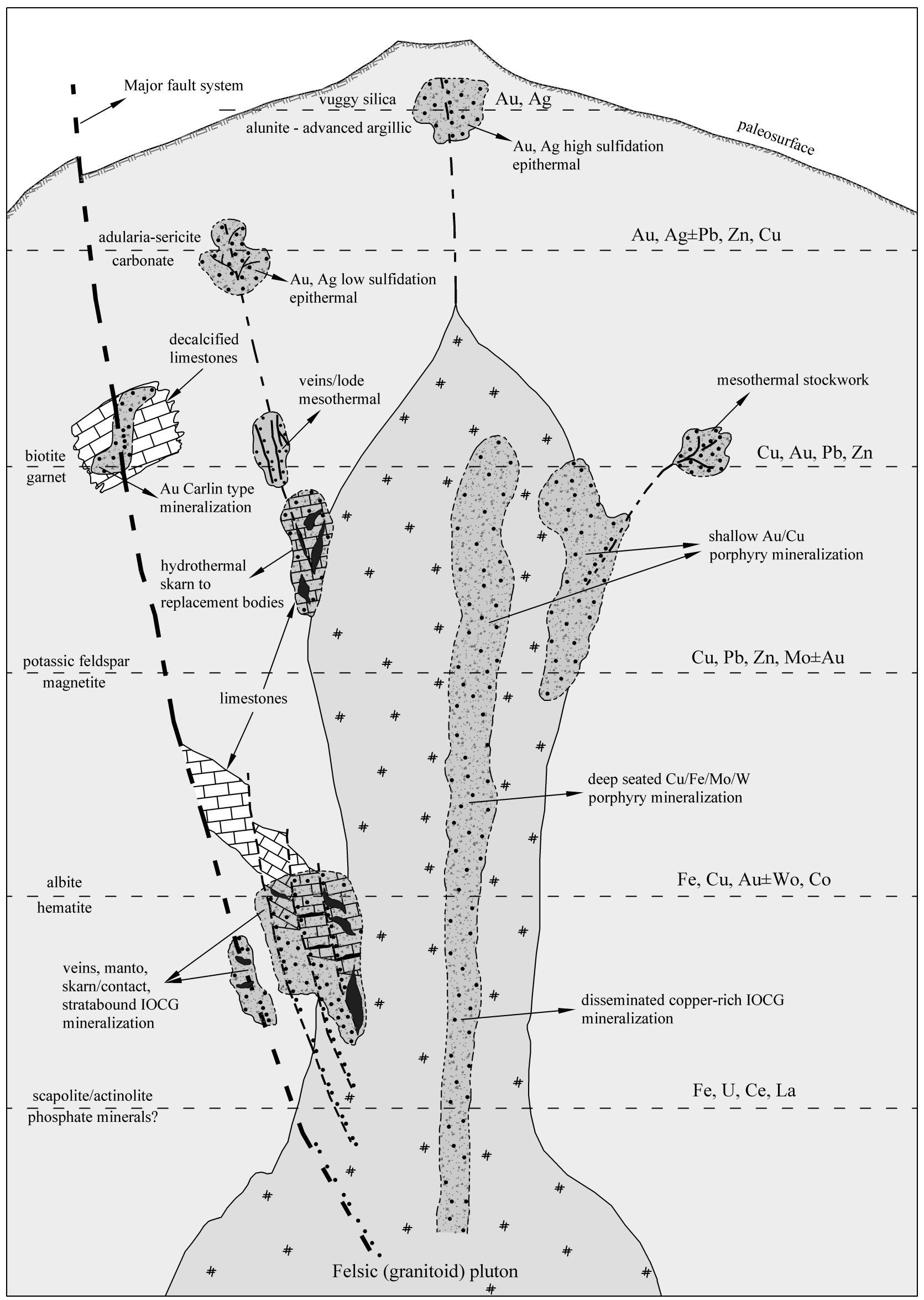

Fig. 1. Conceptual Model-Cross Section through the most important gold bearing geothermal-intrusive related type deposits, showing lateral and vertical metal/alteration zonation. Note that deepest IOCG and porphyry ores are rather associated with Narich metasomatism, while shallow to deep epithermal, mesothermal, and porphyry ores are mainly related to K-rich metasomatism. 
In contrast, the low sulfidation systems occur from reduced-near neutral $\mathrm{pH}$ fluids with large meteoric water input, i.e., gold deposition is often controlled by boiling phenomena. Mineralizing fluids in low sufidation gold bearing environment give rise to open space veins or stockwork like patterns. Carbonate (calcite) and adularia are key alteration minerals, although a deeper sericite-illite assemblage has been recorded frequently. Lower temperature acidic minerals such as cristobalite, kaolinite and alunite could be found in the vadose zone near the paleowater table because of $\mathrm{H}_{2} \mathrm{~S}$ oxidation. Massive opalescent silica layers or silicified plates are usually indicating this zone. Both low sulfidation and high sulfidation systems may lie beneath such steam heated alteration blankets.

By far, epithermal systems are the most productive gold and silver deposits due to their shallow depth, providing opportunities to open pit operations with amazing grades and volumes. For instance, since 1980 the high sulfidation deposit of El Indio-Tambo (Chile) have been producing about $200 \mathrm{t}$ of gold and $1700 \mathrm{t}$ of silver, with much of the ore over $200 \mathrm{~g} / \mathrm{t} \mathrm{Au}$ directly shipped to the metallurgy (Jannas et al., 1990; 1999). Also, the all time production of low sulfidation epithermal deposits of the Gold Quadrilateral (GQ) in Romania was about $50 \mathrm{mil}$. oz of Au from a grand total of 57 mil.oz. yielded in the GQ (Vlad and Orlandea, 2004). Historical milestone deposits mined since Roman times are represented by world class deposits such as Rosia Montana or Barza.

A matter of debate still concerns the deepest epithermal setting, even pluton related, found in the upper part of IOCG deposits. A possible explanation may be linked to the strong tectonic-shearing control that may produce an oxidizing environment at deep depth $(>2 \mathrm{~km})$ or later epithermal overprints which create larger time interval for gold deposition (Filip and Orlandea, 2016).

Most of the low sulfidation deposits are located in extensional-rifting related terrains, including island arcs and back arcs with bimodal volcanism, whilst high sulfidation systems occur in volcanic arcs at convergent plate margins, usually overlying porphyry $\mathrm{Cu}-\mathrm{Au}-\mathrm{Mo}$ ore deposits in subduction zones (Corbett, 2008; Tosdal et al., 2009).

Last, but not least, it seems that the problem of sulfidation degree in IRGS is still not fully understood. It is generally accepted that sulphur bearing fluids represent only a negligible component of magmatic fluids. Sulphur charged vapors and fluids become really abundant in hydrothermal-epithermal phase. Magmatic volatile-vapor dominant are $\mathrm{H}, \mathrm{Cl}, \mathrm{B}, \mathrm{F}$, and $\mathrm{CO}_{2}$, in contrast with epithermal volatile-liquid dominant with $\mathrm{H}_{2} \mathrm{O}, \mathrm{SO}_{2}, \mathrm{SO}_{4}, \mathrm{H}_{2} \mathrm{~S}$, and $\mathrm{CO}_{2}$ (Wallance and Edmonds, 2011). Under such circumstances it is obvious that sulphur and sulfides are the status vector of epithermal systems, but become more complicated and difficult to be used/applied as sulfidation modelling in higher temperature-pressure mesothermal to magmatic environments.

\section{Carlin type deposits}

Initially used to describe a class of carbonate-hosted gold deposits in Nevada, U.S.A., Carlin type mineralization consists commonly of gold disseminations in decalcified (silicified) limestones sequence, showing significant structural-fault control. $\mathrm{Au} / \mathrm{Ag}$ ratios from 3:1 to 5:1 are characteristic of the almost invisible-micronic mineralization with $\mathrm{As}, \mathrm{Sb}, \mathrm{Hg}, \mathrm{Tl}$ geochemical anomalies (Cline et al., 2005).

The magmatic-hydrothermal processes and fluids are proven in Carlin environment as well as a specifically transporting and depositional mechanism that contributes to effective-efficient gold formation (Muntean et al., 2011). Within few kilometers from the surface, the fluids dissolved and sulfidized carbonate wall rocks, leading to deposition of gold bearing pyrite. Carlin deposits of Central Nevada reflect a major thermal event of Great Basin: mineralization formed along with other ore deposits, including giant Bingham Cu-Au-Mo skarn-porphyry and Mount Hope Mo porphyry (Hofstra and Cline, 2000), but Carlin type should be considered a distal-evolved metallogenetic facies.

Commonly high-angle normal faults, but also lowangle or strike-slip fault zones are important controls of mineralization in the larger deposits of Carlin alignment, e.g., Cortez, Carlin, Getchell and Goldstrike (Muntean, 2006). The depth formation of Carlin gold deposits starts probably around $1.5 \mathrm{~km}$ with shearing-gold bearing arsenian pyrite and goes up to shallow epithermal levels $(300 \mathrm{~m})$ in the late ore stage, characterized by open space- quartz, orpiment, realgar and stibnite related to the collapse of hydrothermal system and introduction of near surface meteoric fluids (Ressel and Henry, 2006).

Including past production and mineable reserves, the Carlin District (Nevada) contains the largest and most prolific accumulation of gold deposits in North America. However, the more recently discoved Carlin style ores worldwide (China, Australia, Macedonia, Canada, Brasil, etc.) show sometimes notable differences regarding mineralogy, alteration and fluids chemistry. Supergiant Carlin style tertiary gold deposits include Post Betze system in Carlin district of Nevada, that exceed 35 mil. oz. of Au (Groves et al., 2016) and Dian-QianGui "Golden Triangle" in China, with over 25 mil oz. of $\mathrm{Au}$ (Muntean and Cline, 2018).

\section{Mesothermal and skarn deposits}

Gold bearing mesothermal and skarn deposits associated with dominant magmatic fluids occur due to the circulation of deep crustal fluids (750-3000m) at the contact of or nearby subvolcanic to hypabyssal-plutonic intrusive. The geometry of ore involves stockwork to irregular bodies, lode-veins structures and replacement-lens shaped bodies. Most of the mesothermal lode structures are located in major shear zones and a metamorphic fluid component is sometimes mixed with dominant magmatic-hydrothermal fluids; ore-forming minerals occur at moderate temperature-pressure and the remobilization of some metals $(\mathrm{Cu}, \mathrm{Au})$ during shear zone evolution is presumable when associated with retrograde evolution of the alteration-mineralization system.

A major change in understanding of the complex skarn metallogeny came with the evidence that if the gangue assemblages (garnet, wollastonite, pyroxene, idocrase, etc.) occur at higher temperature, the major part of metallic minerals are hydrothermal (Einaudi and Burt, 1982; Meinert et al., 2005).

Proximal $\mathrm{Cu}-\mathrm{Au}$ skarn mineralization around porphyry systems are the source of massive high grade ore bodies. Examples include Ok Tedi, Ertsberg (Indonesia), Red Dome (Australia), Bingham (USA) and also iron oxides/base metals 
rich $\mathrm{Cu}-\mathrm{Au}$ deposits like Las Pintadas (Chile) and Moldova Noua-Sasca Montana in Romania (Vlad and Berza, 2003). In the Ertsberg-Grasberg world class skarn- porphyry system, the mining operations started because of the early discovery of skarn mineralization - $32 \mathrm{Mt}$ with $2.6 \% \mathrm{Cu}$ and $0.8 \mathrm{~g} / \mathrm{t} \mathrm{Au}-$ formed as roof pendent ore body at the top of Ertsberg equigranular diorite (Prendergast et al., 2005).

$\mathrm{Cu}-\mathrm{Au}+/-$ base metals lode (fault related) and stockworklike structures hosted in non carbonatic rocks exhibit somehow distal position to porphyry intrusive. Type deposits include Umuna, Papua-New Guinee (Adshead and Appleby, 1996) and Kalgoorlie Superpit, West Australia (Bateman and Hagemann, 2004), but also still misinterpreted structures such as Coka Marin, Serbia (Herrington et al., 1998; Jelenkovic et al., 2016) or Andacollo, Chile (Reyes, 1991). Bismuth, tellurium, tin and tungsten are at least anomalous elements in this gold bearing-intrusion related environment (Vlad, 1998).

Giant mesothermal Au lode type deposits like Mother Lode in Sierra Nevada Mts. (California, USA) and Berezovsk in Urals Mts. (Russia) show evidence for multiple metamorphic and magmatic mineralizing fluids, i.e., a hybrid syngeneticepigenetic "orogenic" deposit model being more appropriate (Groves et al., 2003, Vikenteva et al., 2017). However, magmatic-hydrothermal metallogenetic sequences can be distinguished here, for instance the Empire Vein System related to granodiorite porphyry at Mother Lode (Goldfarb et al., 2005) and so called "ladder veins" in granitic dykes at Berezovsk (Vikenteva et al., 2017).

\section{Porphyry deposits}

Porphyry deposits are currently the largest source of copper worldwide, but increasingly important for gold, silver, molybdenum, tungsten and even tin (Sillitoe et al., 1975). Examples of well studied giant porphyry copper deposits include El Teniente and El Salvador in Chile, Bajo de Alumbrera in Argentina, Grasberg in Indonesia and Bingham in the United States (Sinclair, 2007; Sillitoe, 2010).

A variety of criteria have been used to classify porphyry deposits that are generally accepted to be structurallycontrolled complex magmatic-hydrothermal systems. A basic but efficient typology is defined by main commodities, such as copper, molybdenum and gold. However, the current but upgraded level of knowledge indicates that $\mathrm{Cu}-\mathrm{Au}$ and $\mathrm{Au}$ porphyry systems are shallow depth-subvolcanic (sensu largo) systems, in contrast to $\mathrm{Cu}-\mathrm{Mo}(\mathrm{Au}), \mathrm{W}, \mathrm{Mo}, \mathrm{Sn}$ porphyry deposits formed in deep seated-plutonic environments.

The shallow depth (epizonal to mesozonal) subvolcanichypabyssal porphyry systems result commonly from $\mathrm{H}_{2} \mathrm{~S}$ rich magmas i.e., pyrite is stable and widespread. Gold is transported in $\mathrm{Au}[\mathrm{HS}]$ complexes and the salinity of fluids is highly variable. The system is open and evolved oxidized fluids are marked by common boiling phenomena around temperatures of $400-500^{\circ} \mathrm{C}$ and pressures of $0.4-0.5 \mathrm{~kb}$. An important characteristic is this of composite systems, spatially and/or genetically associated with proximal epithermal set of veins, lode to stockwork mesothermal structures and skarn-replacement bodies to disseminated-sediment hosted Carlin type. The major tectonic frame of shallow porphyry occurrence is dominated by extensional terrains and back arccontinental arc settings. Pertinent examples of this kind are provided by deposits such as Roşia Poieni (Romania), Fort
Knox (Alaska, USA), Marte-Lobo, Caspiche (Chile), Red Dome (Australia), Majdanpek (Serbia), Baguio (Philippines) and Lihir (Papua-New Guinee).

The deep-plutonic (mesozonal to hypozonal) porphyry deposits are isobaric to even adiabatic-closed systems where $\mathrm{P}, \mathrm{T}$ parameters frequently control a latent evolution of mineralization-alteration stages. The fluids are still oxidized due to the intense fracturing, but also reduced fluids were recorded under special conditions, e.g., Kidston, Australia (Baker and Andrew, 1991). The magmas are depleted in $\mathrm{H}_{2} \mathrm{~S}$ whereas magnetite is stable and ubiquitous. Gold is transported as $\mathrm{AuCl}_{2}$ complex in dominant hypersaline mineralizing fluids. Early mineralization occurs at temperature beyond $600^{\circ} \mathrm{C}$ and pressures that exceed $2 \mathrm{~kb}$. Many of deep seated porphyry deposits are related to subduction or collision events e.g., the more recently discovered world class orogenic $\mathrm{Cu}$ Mo-Au porphyry system of OyuTolgoi (Mongolia) containing $42 \mathrm{Mt} \mathrm{Cu}$ and $46 \mathrm{Moz} \mathrm{Au}$ (Seltmann et al., 2014).

The association of deep seated porphyry mineralization with IOCG deposits, well known at Cadia and Copper Hill (Gawler Craton, Australia), Andacollo and El Salvador (Chile) and Aitik (Sweden) has been so far ignored in some way. Such a pattern goes from simple spatial zonation or overprinting events up to a gradual passing, as recently observed at deep levels in the famous El Salvador deposit. Moreover, Mo porphyry systems such as Climax \& Henderson (Colorado, USA) and Wo-Sn Mount Pleasant (Canada), roughly speaking, belong to this group (Sinclair, 2007).

The potassic core zone of shallow porphyry consists mainly of secondary biotite, whereas potassic feldspar-magnetite is the main assemblage of deep porphyry systems (Fig.1).

Still controversial giant orogenic deposits such as Muruntau (Uzbekistan), Olimpiada (Russia), Dolin Creek (Alaska, USA) and Abitibi Belt (Canada) where gold is not clearly intrusion related are characterized by major syn-sedimentary or synmetamorphic fluids and deposition processes involved in ore formation. Nevertheless, at least a porphyritic intrusion and possible porphyry gold mineralization event is described in such complex- multiphase systems (Thomson and Newberry, 2000; Genkin et al., 2002; Wall et al., 2004; Borisenko et al., 2014; Meriaud and Jebrak, 2017).

\section{IOCG ore deposits}

Iron Oxides-Copper-Gold (IOCG) group of ore deposits encloses diverse genetic ore types formed in deep conditions $(>2 \mathrm{~km})$. Mesothermal vein-lode, stockwork, breccia pipe systems, plutonic skarn ore bodies, manto type-stratabound and even deep-seated porphyry deposits of different genesis are included in this metallogenetic environment. However, there are multiple common geological features for all IOCG genetic types, besides common mining commodities. The most important is the biotite-scapolite-actinolite alteration for early iron oxides phase (magnetite-mushketovite-hematite) in contrast with the sodium rich (albite) metasomatism for the intermediate main copper stage. Most of the economical gold is associated with late epithermal hematitespecularite bearing potassic alteration event or overprint. Mantle derived granitoid magmas of $\mathrm{M}$ type are involved frequently and minor geochemical anomalies of $\mathrm{U}(\mathrm{Th}), \mathrm{P}$, $\mathrm{Ce}, \mathrm{La}, \mathrm{Sc}, \mathrm{Co}$, and $\mathrm{W}$ are well correlated with major $\mathrm{Fe}, \mathrm{Cu}$, and $\mathrm{Au}$ elements. 
The giant El Salvador porphyry copper deposits of Chile, well known as the first dynamic model of Gustafson and Hunt (1975), offers a better understanding of IOCG group metallogenetic position. Recent mining works show that the deepest part of this deposit is characterized by a significant Na-rich/ albite metasomatism that gradually replaces the potassic alteration, whilst copper grades slightly decrease. Albite-actinolite-magnetite-titanite-epidote association as an ore host is widespread in the core of the system where the porphyritic texture of the intrusion is replaced by the equigranular texture. Almost the same sodic-calcic association is described at Yerington porphyry copper deposit in Nevada, USA (Carten, 1986; Dilles et al., 1992; Halley et al., 2015), where it overlaps the core potassic alteration at 4-6 km depth.

Such vertical zonation of IOCG-porphyry systems both with core albite metasomatism-copper mineralization and iron oxides-gold grades suggest an IOCG-disseminated style that may represent the root zone of deep seated porphyry systems.

The IOCG fluids are dominant magmatic, but also a secondary-highly saline non magmatic fluid component is recorded in particular environments (Barton and Johnson, 1996; Hitzman, 2000, Filip and Orlandea, 2015). Examples of world class IOCG deposits include Olympic Dam, Ernest Henry (Australia), Salabo-Carajas (Brazil), Raul Contestable (Peru), Candelaria, Manto Verde and Mantos Blancos (Chile),
Lyon, Cornwall (Nevada, USA;), Phalaborwa (South Africa), but also Aitik and the Kiruna magnetite-apatite type deposits of Sweden (Williams et al., 2005; Corriveau, 2007).

\section{EXPLORATION TOOLS CHALLENGING NEW GOLD DISCOVERIES}

There are specific criteria and indicators for gold exploration, which effectively direct through the investigation paths for different styles of intrusion related ore deposits. The classical tools, i.e., distinctive mineralogical-petrographic outline, geochemical pathfinder, geophysical signature as well as key alteration minerals, $\mathrm{Au} / \mathrm{Ag}$ ratio, type minerals that contain gold and ore texture/anatomy/color of each type deposit are listed in Table 1. Obviously, modern geochemicalgeophysical tools (ASTER vectoring, 3D Inversion) can be complemented without ignoring classic methods, which need to be updated and integrated into the geological information. Furthermore, some features refer to gold as mining product and/or byproduct in intrusion related environments and the depth formation is probably important to discriminate among different type structures.

Epithermal shallow (0-400 m) or deeper $(400-750 \mathrm{~m})$ gold is chiefly related to felsic rocks in anomalous $\mathrm{Au}, \mathrm{Ag}, \mathrm{Sb}, \mathrm{As}$, $\mathrm{Hg}$, Te, $\mathrm{Se}, \mathrm{Tl}, \mathrm{Pb}, \mathrm{Zn}, \mathrm{Cu}$ zones. The geochemical association

Table 1. Exploration criteria which may be used for Au ore discovery in intrusive-related mineralized environments.

\begin{tabular}{|c|c|c|c|c|c|c|c|c|}
\hline $\begin{array}{l}\text { Expected/ } \\
\text { presumed } \\
\text { structure }\end{array}$ & $\begin{array}{c}\text { Petrographic/ } \\
\text { mineralogic } \\
\text { outline }\end{array}$ & $\begin{array}{l}\text { Geochemic } \\
\text { pathfinder }\end{array}$ & $\begin{array}{c}\text { Geophysical } \\
\text { signature }\end{array}$ & $\begin{array}{c}\text { Key } \\
\text { alteration }\end{array}$ & $\begin{array}{c}A u / A g \\
\text { ratio }\end{array}$ & $\begin{array}{l}\text { Metallic } \\
\text { minerals } \\
\text { containing } \\
\text { gold }\end{array}$ & $\begin{array}{l}\text { Ore texture \& } \\
\text { color }\end{array}$ & $\begin{array}{c}\text { Ore } \\
\text { anatomy }\end{array}$ \\
\hline $\begin{array}{l}\text { Epithermal } \\
\text { Shallow } \\
0-400 \mathrm{~m}\end{array}$ & $\begin{array}{c}\text { felsic rocks,- } \\
\text { no } \mathrm{Px}, \mathrm{Ol}, \\
\text { brown } \mathrm{Hb}\end{array}$ & $\begin{array}{c}\mathrm{Au}, \mathrm{Ag}, \mathrm{Cu}, \\
\mathrm{As}, \mathrm{Sb}, \mathrm{Ge}, \\
\mathrm{Hg}, \mathrm{Te}, \mathrm{Sr}\end{array}$ & $\begin{array}{l}\text { magnetic low, } \\
\text { gravimetric high }\end{array}$ & $\begin{array}{c}\text { alunite, kaolinite } \\
\text { vuggy silica }\end{array}$ & $\begin{array}{l}1: 10- \\
1: 150\end{array}$ & $\begin{array}{l}\text { native gold, } \\
\text { pyrite, } \\
\text { arsenopyrite }\end{array}$ & $\begin{array}{l}\text { whitish soft- } \\
\text { clayed, colloform } \\
\text { silica or quartz, } \\
\text { massive }\end{array}$ & $\begin{array}{l}\text { disseminated, } \\
\text { breccia bodies } \\
\text { stockwork,veins }\end{array}$ \\
\hline $\begin{array}{l}\text { Epithermal } \\
\text { Deeper } \\
400-750 \mathrm{~m}\end{array}$ & $\begin{array}{c}\text { felsic rocks-no } \\
\mathrm{Px}, \mathrm{Ol}, \text { brown } \\
\mathrm{Hb}\end{array}$ & $\begin{array}{l}\mathrm{Au}, \mathrm{Ag}, \mathrm{Te}, \\
\mathrm{Se}, \mathrm{Pb}, \mathrm{Zn}, \\
\mathrm{Sb}, \mathrm{Tl}\end{array}$ & $\begin{array}{l}\text { IP or R high, } \\
\text { magnetic low, } \\
\text { radiometric high }\end{array}$ & $\begin{array}{c}\text { sericite-adularia, } \\
\text { illite } \\
\text { quartz/calcite }\end{array}$ & $\begin{array}{l}1: 1- \\
1: 20\end{array}$ & $\begin{array}{c}\text { pyrite, } \\
\text { telluride, } \\
\text { native gold }\end{array}$ & $\begin{array}{l}\text { soft- grey argillic } \\
\text { or crustiform } \\
\text { quartz, banded }\end{array}$ & $\begin{array}{c}\text { veins, } \\
\text { stockwork } \\
\text { breccia (pipe) }\end{array}$ \\
\hline $\begin{array}{l}\text { Carlin type } \\
300-1500 \mathrm{~m}\end{array}$ & $\begin{array}{l}\text { carbonate- } \\
\text { rich rocks, } \\
\text { deep seated } \\
\text { felsic rocks, } \\
\text { Bi, carbon/ } \\
\text { graphite }\end{array}$ & $\begin{array}{c}\mathrm{Au}, \mathrm{As}, \mathrm{Sb} \\
\mathrm{Hg}, \mathrm{Tl}, \mathrm{Fe} \\
\mathrm{Pb}, \mathrm{Zn}\end{array}$ & $\begin{array}{c}\text { magnetic/ } \\
\text { gravimetric } \\
\text { moderate- high, } \\
\text { IP-R variable }\end{array}$ & $\begin{array}{l}\text { decalcification } \\
\text { (silicification) }\end{array}$ & $\begin{array}{l}2: 1- \\
5: 1\end{array}$ & $\begin{array}{l}\text { arsenian } \\
\text { pyrite, native } \\
\text { gold }\end{array}$ & $\begin{array}{l}\text { hard-black, } \\
\text { laminated, } \\
\text { brecciated, } \\
\text { jasperoidal silica }\end{array}$ & $\begin{array}{l}\text { disseminated, } \\
\text { breccia, } \\
\text { replacement bodies }\end{array}$ \\
\hline $\begin{array}{l}\text { Mesothermal } \\
\text { \& skarn } \\
750-3000 \text { m }\end{array}$ & $\begin{array}{l}\text { felsic to } \\
\text { mafic rocks }+ \\
\text { clinoPx, } \\
\text { limestones or } \\
\text { dolomites }\end{array}$ & $\begin{array}{c}\mathrm{Cu}, \mathrm{Fe}, \mathrm{Zn}, \\
\mathrm{Au}, \mathrm{Ag}, \mathrm{Bi}, \\
\mathrm{Cr}, \mathrm{Ti}, \mathrm{V}\end{array}$ & $\begin{array}{c}\text { magnetic/ } \\
\text { gravimetric highs }\end{array}$ & $\begin{array}{c}\text { chlorite garnet, } \\
\text { wollastonite, } \\
\text { carbonate }\end{array}$ & $\begin{array}{l}2: 1- \\
1: 2\end{array}$ & $\begin{array}{l}\text { pyrite, } \\
\text { wurtzite, } \\
\text { maldonite, } \\
\text { native gold }\end{array}$ & $\begin{array}{c}\text { hard-light/dark, } \\
\text { banded or massive }\end{array}$ & $\begin{array}{l}\text { irregular/lens, } \\
\text { replacement } \\
\text { bodies, } \\
\text { stockwork }\end{array}$ \\
\hline $\begin{array}{l}\text { Porphyry } \\
\text {-shallow depth } \\
750-2000 \mathrm{~m}\end{array}$ & $\begin{array}{c}\text { porphyritic } \\
\text { felsic } \\
\text { intrusive, } \\
\text { phenocrysts }> \\
\text { groundmass } \\
\end{array}$ & $\begin{array}{c}\mathrm{Cu}, \mathrm{Au}, \mathrm{Mo}, \\
\mathrm{Te}, \mathrm{Tl}, \mathrm{Se}, \\
\text { Re, } \mathrm{Zn}\end{array}$ & $\begin{array}{c}\text { magnetic/ } \\
\text { gravimetric/ } \\
\text { radiometric highs }\end{array}$ & $\begin{array}{c}\text { potassic } \\
(\mathrm{Bi}, \mathrm{Fk}), \text { phyllic }\end{array}$ & $\begin{array}{l}1: 2- \\
1: 7\end{array}$ & $\begin{array}{c}\text { pyrite, } \\
\text { chalcopyrite, } \\
\text { bornite }\end{array}$ & $\begin{array}{l}\text { hard-dark, } \\
\text { crustiform to } \\
\text { comb quartz, } \\
\text { compact }\end{array}$ & stockwork \\
\hline $\begin{array}{l}\text { Porphyry } \\
\text {-deep seated } \\
2000-4500 \mathrm{~m}\end{array}$ & $\begin{array}{l}\text { felsic } \\
\text { intrusive, } \\
\text { partly non } \\
\text { porphyritic }\end{array}$ & $\begin{array}{l}\mathrm{Cu} / \mathrm{Mo} / \mathrm{W} \mathrm{Au}, \\
\mathrm{Fe}, \mathrm{Bi}, \mathrm{Ti}, \mathrm{Sn}\end{array}$ & $\begin{array}{l}\text { magnetic high, } \\
\text { radiometric-IP } \\
\text { variable }\end{array}$ & $\begin{array}{c}\text { phyllic, potassic } \\
(\mathrm{Fk}, \mathrm{Bi})\end{array}$ & $\begin{array}{l}1: 7- \\
1: 25\end{array}$ & $\begin{array}{c}\text { pyrite, } \\
\text { chalcopyrite }\end{array}$ & $\begin{array}{l}\text { hard-light, comb } \\
\text { to layered quartz, } \\
\text { compact }\end{array}$ & $\begin{array}{l}\text { stockwork, } \\
\text { breccia pipe }\end{array}$ \\
\hline $\begin{array}{l}\text { IOCG type } \\
2000-5000 \mathrm{~m}\end{array}$ & $\begin{array}{l}\text { felsic to mafic } \\
\text { intrusive+ Px, } \\
\text { Bi, scapolite, } \\
\text { actinolite }\end{array}$ & $\begin{array}{l}\mathrm{Fe}, \mathrm{Cu}, \mathrm{Au} \\
(\mathrm{Co}, \mathrm{W}) \\
\mathrm{U}, \mathrm{Ce}, \mathrm{La}\end{array}$ & $\begin{array}{l}\text { magnetic high, } \\
\text { tabular-parallel IP } \\
\text { alignments }\end{array}$ & $\begin{array}{c}\mathrm{Na}(\mathrm{Ca}) \\
\text { alteration } \\
\text { (albite), potassic } \\
(\mathrm{Bi}, \mathrm{Fk})\end{array}$ & $\begin{array}{c}1: 10- \\
1: 15^{* *}\end{array}$ & $\begin{array}{c}\text { chalcopyrite, } \\
\text { magnetite, } \\
\text { pyrite, } \\
\text { hematite }\end{array}$ & $\begin{array}{l}\text { hard-light/dark, } \\
\text { fibrous to comb } \\
\text { quartz, massive or } \\
\text { breccious }\end{array}$ & $\begin{array}{l}\text { shearing veins, } \\
\text { stockwork, manto*, } \\
\text { lens-replacements, } \\
\text { disseminations }\end{array}$ \\
\hline
\end{tabular}

Legend: $\mathrm{Px}=$ pyroxene; $\mathrm{Ol}=$ olivine; $\mathrm{Hb}=$ hornblende; $\mathrm{Fk}=$ potassic feldspar; $\mathrm{Bi}=$ biotite; $\mathrm{IP}=$ induced polarization; $\mathrm{R}=$ resistivity, $*=$ sub-horizontal low angle fracture controlled mineralization **= only when both $\mathrm{Au}$ and $\mathrm{Ag}$ commodities are present in IOCG system. 
is constantly superposed on low magnetic and electrometric (IP-R) or radiometric highs as geophysical signature that suggests advanced to intermediate argillic key alteration with/without sericite-adularia, depending on the degree of sulfidation. $\mathrm{Au} / \mathrm{Ag}$ ratio is distinctive, i.e., between 1:10-1:150 for shallow levels and 1:1-1:20 range for deeper epithermal mineralization, where gold is present as native gold, tellurides or included in pyrite and arsenopyrite. Commonly, ore anatomies consist of veins or dissemination/stockwork to breccia pipe bodies with soft-clayed whitish-light grey colors and collomorf-crustiform-vuggy or massive/banded textures.

Sometimes called sediment-hosted disseminated gold deposits, but definitely of magmatic origin, the Carlin type gold could be formed at epithermal depths (300-800 m), but also exceeding $1000 \mathrm{~m}$, when a minor metamorphic fluid component is recognized (Cline et al., 2005). Decalcified (silicified) limestones with interlayered organic carbon-rich zones and deep seated felsic biotite bearing intrusive rocks, both with $\mathrm{Au}, \mathrm{As}, \mathrm{Sb}, \mathrm{Hg}, \mathrm{Tl}, \mathrm{Pb}$, and $\mathrm{Zn}$ anomalies and moderate to high magnetic and gravimetric are characteristic of this mineralized environment. Typical $\mathrm{Au} / \mathrm{Ag}$ ratio ranges between 2:1-5:1 and gold is found entirely as micronsize inclusions in arsenian pyrite or hematite, if oxidized. Disseminated, partly brecciated, irregular bodies are dominant and hard-black, laminated-rhythmic layered or jasperoid ore textures are frequently observed.

Mesothermal and skarn gold occur mostly at 750-3000 m depth and associate with felsic to mafic igneous rocks or contact limestones. Typical geochemical anomalies contain $\mathrm{Au}, \mathrm{Ag}, \mathrm{Cu}, \mathrm{Fe}, \mathrm{Zn}, \mathrm{Bi}, \mathrm{Ti}, \mathrm{Cr}$, and $\mathrm{V}$ with complementary magnetic/gravimetric geophysical highs. Garnet, chlorite, wollastonite and carbonate alteration is important to locate ore bodies wherein $\mathrm{Au} / \mathrm{Ag}$ ratio varies between 2:1-1:2. Gold is included commonly in minerals such as pyrite, bornite, wurtzite/marmatite and maldonite. The ores are hard-dark/ light colored, banded or massive and consist of irregular to lens-shaped replacement bodies or stockwork-like structures.

Gold in porphyry environment should be seen today as bearing a double typology, depending on depth formation, i.e., shallow depth porphyry $(750-2000 \mathrm{~m})$ versus deep seated porphyry $(2000-4500 \mathrm{~m})$. Both mineralized systems are related to felsic (subvolcanic to abyssal) intrusive rocks, but the geochemical association and the major metals are different. $\mathrm{Cu}-\mathrm{Au}$ deposits in a minor aureole of $\mathrm{Mo}, \mathrm{Te}, \mathrm{Tl}$, $\mathrm{Se}, \mathrm{Re}, \mathrm{Zn}$ are related to the shallow porphyry, in contrast to $\mathrm{Cu}-\mathrm{Mo}-\mathrm{Au}, \mathrm{Mo}-\mathrm{W}, \mathrm{Au}, \mathrm{Sn}$ deposits with minor Fe, Bi, Ti that are characteristic of deep seated porphyry. Mixture of these elements suggests a transitional depth facies or very particular thermobaric conditions in the evolution of mineralizationalteration process. Magnetic and radiometric/gravimetric and variable IP geophysical highs designate the core of the system, but the key potassic-phyllic alterations contain more secondary biotite at shallow depth and more potassic feldspar in deep seated environments. Chalcopyrite and pyrite may include gold in both systems, but bornite contains gold especially in shallow depth porphyry. Stockwork-like shapes are common for all the porphyry systems, whilst breccia pipe structures appear chiefly in deep seated porphyry deposits.

Iron Oxides-Copper-Gold (IOCG) deposits are probably the deepest metallogenetic formation $(2000-5000 \mathrm{~m})$ related to felsic intrusions, where biotite, pyroxene and scapolite are constantly recorded. The geochemical pathfinder is composed by major $\mathrm{Fe}, \mathrm{Cu}, \mathrm{Au}$ and minor $\mathrm{Co}, \mathrm{W}, \mathrm{U}, \mathrm{Ce}, \mathrm{P}$, La anomalous elements, often correlated with geophysical magnetic highs and parallel IP-chargeability alignments. The key alteration mineral to copper deposition is albite, whereas potassic associations are related to $\mathrm{Fe}$ and $\mathrm{Au}$ deposition stages. Gold is included in minerals such as chalcopyrite, pyrite and hematite, at least three different gold stages being separated in IOCG environments in Atacama, Chile (Filip and Orlandea, 2016). The IOCG ore bodies consist of shearing veins, stockwork to disseminated ore, lens shaped to irregular contact bodies, manto type (low angle fault controlled) to stratabound mineralization with fibrous, massive or brecciated ore textures.

However, the prevalence of macroscopically invisible gold usually make hard to decide where, what and how to sample/ estimate gold in different intrusion related environments. A new approach on minerals hosting gold with estimated gold grades is exposed in the Table 2, based on field observations, mineralogical studies and grades control in gold explorationmining activities developed or conducted by the authors.

Magnetite-muschetovite in a potassic proximal aureole contains low grade gold (up to $0.3 \mathrm{~g} / \mathrm{t}$ ) in deeper mesothermal to IOCG mineralized systems. Later specularite (even if epithermal) in carbonate alteration at deep seated IOCG deposits hosts economical gold grading between 1-5 g/t.

Pyrite includes gold all over intrusion related environments, but pentagonal-triangular shaped crystals are a more favorable host for gold deposition. Additionally, a sericite-illite proximal wall rocks alteration of deep shearing fractures may increase gold grades in pyrite up to $3 \mathrm{~g} / \mathrm{t}$. Shallow depth marcasite may contains subeconomical gold (up to $0.6 \mathrm{~g} / \mathrm{t}$ ), but inevitably in highly oxidized twined crystals with denticulate-blade aspects.

Quartz is an important mineral that carry gold/ 0.5-1.5 g/t, mostly in grey-violet or dark-comb textures which appear in epithermal to shallow depth porphyry systems, in contrast to gold bearing colloform to jasperoid brown-reddish quartz in deeper mesothermal to IOCG environments.

Up to $0.8 \mathrm{~g} / \mathrm{t}$ gold may be found in intermediate argillic zones of epithermal-porphyry deposits wrapping a soft adularia-hydromicas assemblage. Low gold grades (up to $0.2 \mathrm{~g} / \mathrm{t}$ ) it have been found in pinkish calcite with anomalous manganese content.

Copper minerals (chalcopyrite, bornite) represent a valuable host of gold in many intrusion related environments (gold range 0.4 to $4 \mathrm{~g} / \mathrm{t}$ ). Gold bearing copper mineralization shows major oxidation with reddish shades in association with potassic or sodic feldspar and milky quartz.

Gold behavior in deeper epithermal-mesothermal sphalerite is less known to date, but it seems that only Ferich blackish marmatitic sphalerite and wurtzite contain low gold up to $0.4 \mathrm{~g} / \mathrm{t}$. Worth to be mentioned is that similar gold grades in shallow epithermal environments are correlated with fibrous sulfides and sulfosalts, e.g., stibnite and jamesonite.

By far, the highest gold grades are found in megascopic (even sub-millimetric) native gold $(>15 \mathrm{~g} / \mathrm{t} \mathrm{Au})$ and gold telluride $(>3 \mathrm{~g} / \mathrm{t} \mathrm{Au})$ samples. Always the native gold grains are accompanied by dark bands of rich-iron oxides, whereas the gold tellurides are associated with proximal pink-yellowish potassic and/or manganese oxides/sulfides alterations. 
Table 2. Exploration tools to find and estimate gold grades in Hydrothermal-Porphyry-IOCG style ore.

\begin{tabular}{|c|c|c|c|c|}
\hline \multicolumn{2}{|c|}{ Minerals hosting gold } & $\begin{array}{l}\text { Epithermal \& porphyry } \\
\text { Mineral aspects }\end{array}$ & $\begin{array}{l}\text { Mesothermal \& iocg } \\
\text { Mineral aspects }\end{array}$ & $\begin{array}{l}\text { Estimated } \\
\text { Sample } \\
\text { Gold grade }\end{array}$ \\
\hline \multicolumn{2}{|l|}{ Magnetite } & - & $\begin{array}{l}\text { Magnetite-mushketovite with curved plates } \\
\text { shapes, fine biotitization and/or potassic } \\
\text { feldspar proximal alteration }\end{array}$ & $0.05-0.3 \mathrm{~g} / \mathrm{t}$ \\
\hline \multicolumn{2}{|l|}{ Hematite } & - & $\begin{array}{c}\text { Silver-grey specular hematite often, } \\
\text { carbonate rich (rhombohedral calcite) } \\
\text { environment }\end{array}$ & $1.0-5.0 \mathrm{~g} / \mathrm{t}$ \\
\hline \multicolumn{2}{|l|}{ Pyrite } & \multicolumn{2}{|c|}{$\begin{array}{c}\text { Pentagonal shapes mainly, no striae on the gold bearing pyrite faces, green sericite- } \\
\text { intermediate argillic wall rock alteration, shearing fractures }\end{array}$} & $0.1-3.0 \mathrm{~g} / \mathrm{t}^{*}$ \\
\hline \multicolumn{2}{|l|}{ Marcasite } & $\begin{array}{c}\text { Always strongly oxidized twined gold } \\
\text { bearing marcasite crystals, vuggy texture }\end{array}$ & - & $0.1-0.6 \mathrm{~g} / \mathrm{t}$ \\
\hline \multicolumn{2}{|l|}{ Quartz } & $\begin{array}{l}\text { Only grey-violet, grey dark, semi } \\
\text { translucent to opaque, comb quartz }\end{array}$ & $\begin{array}{l}\text { Colloform to jasperoidal translucent to } \\
\text { brownish or reddish quartz }\end{array}$ & $0.5-3.5 \mathrm{~g} / \mathrm{t}$ \\
\hline \multicolumn{2}{|l|}{ Clay minerals } & $\begin{array}{l}\text { Sericite-illite }+/ \text { - adularia, quartz soft } \\
\text { rocks, grey -whitish, fatly aspect }\end{array}$ & - & $0.2-0.8 \mathrm{~g} / \mathrm{t}$ \\
\hline \multicolumn{2}{|l|}{ Calcite } & \multicolumn{2}{|c|}{ Pinkish appearance /shades in gold bearing calcite due to Mn oxides/carbonates } & $0.1-0.2 \mathrm{~g} / \mathrm{t}$ \\
\hline \multirow{3}{*}{ Base metal sulfides } & \begin{tabular}{|l|}
$\begin{array}{l}\text { Chalcopyrite/ } \\
\text { bornite }\end{array}$ \\
\end{tabular} & \multicolumn{2}{|c|}{$\begin{array}{l}\text { Always strongly oxidized, reddish shades on gold bearing chalcopyrite-bornite, potassic } \\
\text { feldspar or albite bearing proximal alteration, milky quartz }\end{array}$} & $0.2-4.0 \mathrm{~g} / \mathrm{t}^{* *}$ \\
\hline & Sphalerite & $\begin{array}{l}\text { Only in rich Fe blackish marmatitic } \\
\text { sphalerite or hexagonal (wurtzite) }\end{array}$ & - & \multirow{2}{*}{$0.1-0.4 \mathrm{~g} / \mathrm{t}$} \\
\hline & \begin{tabular}{|l|}
$\begin{array}{l}\text { Other sulfide/ } \\
\text { sulfosalts }\end{array}$ \\
\end{tabular} & $\begin{array}{l}\text { Commonly in/with fibrous minerals, e.g. } \\
\text { jamesonite, stibnite }\end{array}$ & - & \\
\hline \multicolumn{2}{|l|}{ As visible native gold } & \multicolumn{2}{|c|}{ Always with/in blackish to reddish-brown bands of rich Fe oxides and sulfides } & $>15.0 \mathrm{~g} / \mathrm{t}$ \\
\hline \multicolumn{2}{|l|}{ Telluride } & $\begin{array}{c}\text { Silica-saturated rocks, potassic feldspar, } \\
\text { pinky-yellowish proximal selvage/ } \\
\quad \text { alteration } \\
\text { Whitish shinny metallic luster +/-Mn- } \\
\text { sulfides or oxides (black, green, pink) }\end{array}$ & - & $>3.0 \mathrm{~g} / \mathrm{t}$ \\
\hline
\end{tabular}

$*<1 \mathrm{~g} / \mathrm{t} \mathrm{Au}$ in epithermal to porphyry and $>1 \mathrm{~g} / \mathrm{t} \mathrm{Au}$ in mesothermal to IOCG mineralization; $* *<0.5 \mathrm{~g} / \mathrm{t}$ in epithermal to porphyry and variable (up to $4 \mathrm{~g} / \mathrm{t}$ ) in mesothermal to IOCG mineralization.

Last, but not least, having favorable gold grades it not enough and a satisfactory recovery of gold is necessary as well. Dominant coarse free gold (native) is easily recovered using gravitational and amalgamation methods. When the most important part of gold is included in sulfides-sulfosalts, the flotation process is the most suitable. For instance a great recovery of gold is recorded in copper concentrates from porphyry $\mathrm{Cu}-\mathrm{Au}$ (Mo) deposits due to the strong-positive geochemical correlation between gold and copper. When the most important part of the gold is free, but micronic, or encapsulated in gangue minerals, cyanide leaching is applied to the ore. However if gold is refractory, i.e., associated with As, Sb, Te, and organic carbon/graphite (e.g., some Carlin or high sulfidation type deposits) a pretreatment of roasting/fine grinding and oxidation/ bio-oxidation/ pressure oxidation/ Albion oxidation increase the gold recovery. Final metallurgical methods involve mainly gold electrowinning -(electro)refining and the recovery may reach up to $95 \%$ $\mathrm{Au}$ or even more, when most suitable processes have been used.

\section{DISCUSSIONS AND CONCLUSIONS}

The aim of this paper is to design an exclusive metallogenetic model of intrusion related deposits wherein gold could be found in dual position, that is from a major player to a mere byproduct. At the same time this genuine conceptual outcome tries to avoid as much as possible controversial or confusing themes such as early IRGS typology, intermediate sulfidation meaning, orogenic gold and dominant sedimentary source of IOCG metals. The result is a more simplified but accomplished model, wherein the root zone is covered by IOCG, somehow bellow and beyond the deep seated porphyry environment. Accordingly, the vertical metal zonation initiates with paleosurface epizonal $\mathrm{Au}, \mathrm{Ag}-\mathrm{Cu}, \mathrm{Pb}, \mathrm{Zn}$, continues with mesozonal $\mathrm{Cu}, \mathrm{Au}-\mathrm{Cu}$, $\mathrm{Mo}$, and completes at hypozonal levels with $\mathrm{Fe}, \mathrm{Cu}, \mathrm{Au}-\mathrm{Co}$, $\mathrm{W}, \mathrm{U}, \mathrm{Ce}, \mathrm{La}$. Igneous lithogenic I type granitic as well as mantle derived $\mathrm{M}$ type granitoid magmas are involved as a source of gold bearing fluids, especially in the case of deep seated mineralized systems.

Alunite-kaolinite-vuggy silica advanced argillic alteration is characteristic of epithermal-high sulfidation processes, in contrast to adularia-sericite-carbonate assemblage, typical for epithermal low sulfidation environment.

Biotite is significant as concerns Carlin type gold hosted in silicified, carbon-rich limestones as well as potassic alteration in shallow porphyry systems. Carlin mineralization may be deposited at variable, epizonal to mesozonal depths with early arsenian pyrite and late open space-distal orpiment, realgar and stibnite, when system collapses and meteoric fluids are mixed with magmatic-hydrothermal ones.

Chlorite/epidote-garnet-wollastonite associations suggest a deeper mesothermal to skarn mineralized formation. Plenty of mesothermal gold bearing structures involve shearing fractures or tabular shear zones (lodes) and consequently a possible metamorphic fluid component or remobilization of metals from pre-existing sources. Besides this, the meaning of skarn deposits developed during the last decades in terms of polyascendant formation, i.e., ore deposition overlapping 
early polystadial-tardimagmatic and/or high temperature postmagmatic skarn.

Porphyry deposits can be simply divided in two groups, using criteria of depth formation and major commodities. The shallow depth porphyry group is $\mathrm{Cu}-\mathrm{Au}$ or $\mathrm{Au}$ epizonal to mesozonal mineralization formed and deposited in openoxidized and composited systems, whereas the deep seated porphyry group is mesozonal to hypozonal, containing $\mathrm{Cu}-\mathrm{Mo}$ $\mathrm{Au}$ ) or $\mathrm{W} / \mathrm{Fe} / \mathrm{Sn}$ occurring from oxidized to reduced fluids in isobaric-adiabatic closed systems. Note that the second group is spatially and genetically associated with IOCG ore deposits.

Potassic feldspar (orthoclase-microcline) and sodic plagioclase (albite), both with iron oxides, scapolite and actinolite, are characteristic of deep seated porphyry or IOCG gold bearing ore deposits. A interesting expression of IOCG mineralization is the atypical epithermal suite still preserved sometimes in the apex of the pluton, explained by means of a substantial tectonic-major fault control which produce alignments of intense oxidation and introduction of meteoric water into the system.

Gold in intrusion related IOCG environment is associated mainly with latest epithermal event or overprint and is included in pyrite or specular hematite, but at least two additional types of gold, i.e., magnetite and chalcopyrite related, is described in Chilean IOCG deposits (Filip and Orlandea, 2016). The depth of the vertical zoning shows that the IOCG environment may represent the root zone of deep seated porphyry systems. Still controversial remain some of the "orogenic" gold deposits, often associated with non magmatic fluids and activities.

A return to classic, but updated, exploration tools is recommended, providing leverage to understanding the geological setting and its ore potential. Selective tools for gold occurrences in intrusion related environments, separated by depth formation, consist of critical petrographicmineralogical characteristics, geochemical pathfinder elements, key alteration, $\mathrm{Au} / \mathrm{Ag}$ ratio, minerals hosting gold, ore color, texture and anatomy/shape. Some metallic or gangue minerals that include gold in shallow or deep seated intrusion related systems are magnetite, hematite, pyrite, marcasite, quartz, clay minerals, calcite, $\mathrm{Cu}-\mathrm{Pb}-\mathrm{Zn}$ sulfides and sulfosalts, native gold and tellurides. Estimation of gold grade for each mineral bearing sample could be a relevant tool, especially in the preliminary phases of regional exploration and more then that, the relationship between gold mineralogy and ore processing/metallurgy is important for selecting the suitable methods which run finally to a very good recovery of gold.

\section{REFERENCES}

Adshead, N., Appleby, A.K., 1996, The Umuna Au-Ag deposit, Misima Island, Papua-New Guinee; spatial but not genetical associated with porphyry. Proceedings of the Porphyry related copper and gold deposits of Asia-Pacific Region, Australian Mineral Foundation, Adelaide: 14.114.10 .

Baker, E.M., Andrew, A.S., 1991, Geologic, fluid inclusions, and stable isotope studies of the gold-bearing breccia pipe at Kidston, Queensland, Australia. Economic Geology, 86: 810-830. https://doi.org/10.2113/gsecongeo.86.4.810
Barton, M.D., Johnson, D.A., 1996, Evaporitic-source model for igneous related $\mathrm{Fe}$ oxides (REE-Cu-Au-U) mineralization. Geology, 24: 259-262. https://doi.org/10.1130/0091-7613 (1996)024\%3C0259:ESMFIR\%3E2.3.CO;2

Barton, M.D., Johnson, D.A., 2000, Alternative brine source for $\mathrm{Fe}$ oxides $(\mathrm{Cu}-\mathrm{Au})$ systems: implications for hydrothermal alteration and metals. In Hydrothermal IOCG \& related deposits: A global perspective (Porter, T.M., Ed.), Australian Mineral Foundation, 1: 43-60.

Bateman, R., Hagemann, S., 2004, Gold Mineralization throughout about 45 MA of Archean orogenenesis; protracted flux of gold in Golden Mile, Yilgarn craton, Western Australia. Mineralium Deposita, 39: 1661-1678. https://doi.org/10.1007/s00126-004-0431-2

Borisenko, A.S., Sazanov, A.M., Nevolko, P.A., Naumov, E.A., Tessalina, S., Kovalev, K.R. \& Sukhorukov, V.P., 2014, Gold Deposits of the Yenisey Ridge (Russia) and age of its formation. Acta Geologica Sinica, 88 (2): 686-687. https://doi.org/10.1111/1755-6724.12375 4

Carten, R.B., 1986, Sodium-calcium metasomatism, chemical, temporal and spatial relationship at the Yerington-Nevada porphyry copper deposit. Economic Geology, 81: 1495-1519. https://doi.org/10.2113/gsecongeo.81.6.1495

Clark, G.H., 1990, Panaguna copper-gold deposit. In Geology of Mineral Deposits of Australia and PNG (Hughes, F.E., Ed.), Australian Institute of Mining and Metallurgy, 2: 1807-1816.

Cline, J.S., Hofstra, A.H., Muntean, J.L., Tosdal, R.M. \& Hickey, K.A., 2005, Carlin Type gold deposits in Nevada: critical geological characteristics and viable models. Economic Geology, 100 ${ }^{\text {th }}$ Anniversary Volume, p. 451-484. https://doi.org/10.5382/AV100.15

Coggon, J., 2004, Magnetism-the key to the Wallaby gold deposit. Exploration Geophysics, 34: 125-130. https://doi.org/10.1071/EG03125

Corbett, C.J, 2008, Influence of Magmatic arc geothermal systems in porphyry-epithermal $\mathrm{Au}-\mathrm{Ag}-\mathrm{Cu}$ exploration Models. XLVIII Terry Leach Symposium, Australian Institute of Geosciences, 48: 25-43.

Corbett, G.J., Leach, T.M. (Eds.), 1997, Southwest Pacific Rim Gold Copper Systems: Structure, Alteration and Mineralization, Short Course Manual, Sydney, 235 p. https://doi.org/10.5382/SP.06

Corriveau, L., 2007, A synthesis of major deposit types, district metallogeny, the evolution of geological provinces and exploration methods. In Geological Association of Canada, Mineral Deposits Division, 5: 307-328.

Dilles, J.H., 2012, Footprints of porphyry $\mathrm{Cu}$ deposits: Vectors to the hydrothermal center using mineral mapping and lithogeochemistry. Final technical report. http://minerals.usgs.gov/mrerp/reports/Dilles-G10AP00052.pdf

Dilles, J.H., Solomon, G.C., Taylor, H.P. \& Einaudi, M.T., 1992, Oxygen and hydrogen isotope characteristics of the Ann Mason porphyry copper deposit, Yerington, Nevada. Economic Geology, 88: 44-63.

https://doi.org/10.2113/gsecongeo.87.1.44

Einaudi, T.M., Burt, D.M.,1982, Introduction, terminology, classification and composition of skarn deposits. Economic Geology, 77: 745-754.

https://doi.org/10.2113/gsecongeo.77.4.745 
Filip, I., Orlandea, E., 2015, Evolution and timing of alteration-mineralization processes in Tigresa-Transito IOCG vein deposits from Ojancos Tectonic Alignments, Atacama Region, Chile. Carpathian Journal of Earth and Environmental Sciences, 10 (2): 247-260.

Filip, I., Orlandea, E., 2016, Gold position and distribution in Lower Cretaceous IOCG deposits of Copiapo Basin, Atacama Region, Chile. Carpathian Journal of Earth and Environmental Sciences, 11 (1): 89-104.

Fraser, G.L., Skirrow, R.G., Schmidt-Mumm, A. \& Holm, O., 2007, Mesoproterozoic gold in the central Gawler Craton, South Australia: Geology, alteration, fluids and timing. Economic Geology, 102: 1511-1539.

https://doi.org/10.2113/gsecongeo.102.8.1511

Gammons, C.H., Williams-Jones, A.E.,1997, Chemical mobility of gold in porphyry-epithermal environment. Economic Geology, 92: 45-59.

https://doi.org/10.2113/gsecongeo.92.1.45

Genkin, A.D., Wagner, F.E., Krylova, T.L. \& Tsepin, A.I., 2002, Gold bearing arsenopyrite and conditions of its formation at the Olimpiada and Veduga gold deposits (Yenisey Ridge, Syberia). Geology of Ore Deposits, 44 (1): 52-68.

Goldfarb, R.J., Baker, T., Dupe, B. \& Gosselin, P., 2005, Distribution, character and genesis of gold deposits in metamorphic terrains. Economic Geology $\left(100^{\text {th }}\right.$ Anniversary Volume), 407-450.

https://doi.org/10.5382/AV100.14

Groves, D.I., Goldfarb, R.J., Robert, F. \& Hart, C.J.R., 2003, Gold deposits in metamorphic belts: an overview of current understanding-outstanding problems, future research and exploration significance. Economic Geology, 98: 1-29.

https://doi.org/10.2113/gsecongeo.98.1.1

Groves, D.I., Goldfarb, R.J. \& Santosh, M., 2016, The conjunction of factors that lead to formation of giant gold provinces and deposits in non-arc settings. Geoscience Frontiers, 7: 303-314.

https://doi.org/10.1016/j.gsf.2015.07.001

Gustafson, L.B., Hunt, J.P., 1975, The porphyry copper deposit at El Salvador, Chile. Economic Geology, 70: 857912. https://doi.org/10.2113/gsecongeo.70.5.857

Halley, S., Dilles, J.H. \& Tosdal, R.M., 2015, Footprints: Hydrothermal alteration and geochemical dispersion around porphyry copper deposits. Society of Economic Geologists Newsletter, 100: 12-17.

Hart, C.R.J., 2005, Classifying, distinguishing and exploring for intrusion-related gold systems. The Gangue, Geological Association of Canada, Mineral Deposits Division, 87 (1): 4-9.

Hart, C.J.R., Mc Coy, D., Goldfarb, R.J., Smith, M., Roberts, P., Hulstein, R., Bakke, A.A. \& Bundtzen, T.K., 2002, Geology, exploration and discovery of Tintina gold province, Alaska and Yukon. Society of Economic Geologists Special Publication, 9: 241-274.

https://doi.org/10.5382/SP.09.12

Hedenquist, J.V., Arribas, A.R. \& Gonzales-Urien, E., 2000, Exploration for epithermal gold deposits, Society of Economic Geologists Reviews, 13: 245-277. https://doi.org/10.5382/Rev.13.07
Heinrich, C.A., 2015, Witwatersrand gold deposits formed by volcanic rain, anoxic rivers and Archaean life. Nature Geosciences, 8: 206-209.

https://doi.org/10.1038/ngeo2344

Holliday, J. R., Cooke, D. R., 2007, Advances in geological models and exploration methods for copper \pm gold porphyry deposits. In Proceedings of Exploration 07: Fifth Decennial International Conference on Mineral Exploration, 53: 791-809.

Herrington, R, Jankovic, S. \& Kozelj, D., 1998, The Bor and Majdanpek copper gold deposits in the context of the Bor metallogenetic zone (Serbia, Yugoslavia). In Porphyry and hydrothermal copper-gold deposits: a global perspective (Porter, T.M., Ed.), PGC Publishing, Adelaide, 1: 185-194.

Hitzman, M.V., 2000, Iron Oxide-Cu-Au deposits: what, where, when and why. In Hydrothermal iron oxides-coppergold deposits: a global perspective (Porter, T.M., Ed.), PGC Publishing, Adelaide, 1: 9-25.

Hofstra, A.H., Cline, J.S., 2000, Characteristics and models for Carlin type gold deposits. Economic Geology, 13: 163220. https://doi.org/10.5382/Rev.13.05

Jelenkovic, R., Milovanovic, D., Kozelj, D. \& Banjesevic, M., 2016, The mineral resources of the Bor Metallogenic Zone: A review. Geologia Croatica, 1: 143-155. https://doi.org/10.4154/GC.2016.11

Jannas, R.R., Beane, R.E., Ahler, B.A. \& Brosnahan, D.R., 1990, Gold and copper mineralization at El Indio deposit, Chile. Journal of Geochemical Exploration, 35: 197-232.

Jannas, R.R., Bowers, T.S., Petersen, U. \& Beane, R.E., 1999, High sulfidation deposit types in El Indio district, Chile. Economic Geology, Special Publication, 7: 219-266. https://doi.org/10.5382/SP.07.07

Kelley, D.L., Kelley, K.D., Coker, W.B., Caughlin, B. \& Doherty, M.E, 2006, Beyond the obvious limits of ore deposits: the use of mineralogical, geochemical and biological features of the remote detection of mineralization. Economic Geology, 101: 729-752.

https://doi.org/10.2113/gsecongeo.101.4.729

Lang, J.R., 2001, Regional and system scale controls on the formation of copper and/or gold magmatic-hydrothermal mineralization. University of British Columbia, Mineral Department Unit, Special Publication, 2, 115 p.

Lang, J.R., Baker, T., Hart, C.J.R. \& Mortensen, J.K., 2000, An exploration model for intrusion related gold systems. Society of Economic Geologists Newsletter, 40: 6-14.

Lang, J.R., Baker, T., 2001, Intrusion related gold systems; the present level of understanding. Mineralium Deposita, 36: 477-489. https://doi.org/10.1007/s001260100184

Lindgren, W., 1922, A suggestion for the terminology of certain mineral deposits. Economic Geology, 17: 292-294. https://doi.org/10.2113/gsecongeo.17.4.292

Lowerstern, J.B., 2001, Carbon dioxide in magmas and implication for hydrothermal systems. Mineralium Deposita, 36: 490-502. https://doi.org/10.1007/s001260100185

Martinsson, O., Virkkunen, R., 2004, Geology and metallogeny of the Northern Norrbotten $\mathrm{Fe}$-Cu-Au province. In Volcanic associated $\mathrm{Zn}-\mathrm{Cu}-\mathrm{Au}-\mathrm{Ag}$, intrusion associated $\mathrm{Cu}-\mathrm{Au}$, sediment hosted $\mathrm{Pb}-\mathrm{Zn}$ and magnetite-apatite deposits in Northern Sweden. Society of Economic Geologists, Guidebook, 32: 167-172. 
Marschik, R., Fontbote, L., 2001, The Candelaria-Punta del Cobre Iron Oxides-Cu-Au (Zn-Ag) deposits, Chile. Economic Geology, 96: 1799-1826.

https://doi.org/10.2113/96.8.1799

Meier, D.L., Heinrich, C.A. \& Watts, M.A., 2009, Mafic dykes displacing Witwatersrand gold reefs: evidence against metamorphic-hydrothermal ore formation. Geology, 37: 607-610. This book is a translation from the original.This book is a translation from the original.

https://doi.org/10.1130/G25657A.1

Meinert, L.D., Dipple, G.M. \& Nicolescu, Ș., 2005, World skarn deposits, Economic Geology $\left(100^{\text {th }}\right.$ Anniversary Volume), 299-336.

Meriaud, N., Jebrak M., 2017, From intrusion related to orogenic mineralization: the Wasamac deposit, Abitibi Greenstones Belt, Canada. Ore Geology Reviews, 84: 289308. https://doi.org/10.1016/j.oregeorev.2017.01.021

Moyle, A.J., Doyle, B.J., Hoogvliet, H. \& Ware, A.L., 1990, Landolam Gold deposits, Lihir Island. In Geology of Mineral Deposits of Australia and PNG. (Hughes, F.E. Ed.), Australian Institute of Mining and Metallurgy, 14: 1793-1805.

Muntean, J.L., 2006, Major precious deposits in Nevada mineral industry 2005, Nevada Bureau of Mining and Geology, Special Report, p. 29-51.

Muntean, J.L., Cline, J.S., 2018, Diversity of Carlin style gold deposits. Reviews in Economic Geology, 20: 1-5.

https://doi.org/10.5382/rev.20

Muntean, J.L., Cline, J.S., Simon, A.C. \& Longo, A.A., 2011, Magmatic-hydrothermal origin of Nevada's Carlin-type deposits. Nature Geosciences, 4: 122-127.

https://doi.org/10.1038/ngeo1064

Mustard, R., 2001, Granite hosted gold mineralization at Timbarra, Northern New South Walles, Australia. Mineralium Deposita, 36: 542-562. https://doi.org/10.1007/s001260100188

Mustard, R., 2004, Textural, mineralogical variation in the zoned Timbarra Tableland pluton, New South Walles. Australian Journal of Earth Sciences, 51: 385-405. https://doi.org/10.1111/j.1400-0952.2004.01064.x

Porter, T.M., 2015, The geology, structure and mineralization of the Oyu Tolgoi porphyry copper-gold-molybdenum deposit, Mongolia. Reviews in Geosciences Frontiers, XXX: 1-33.

Prendergast, K., Clark, G.H., Pearson, N. \& Harris, K., 2005, Genesis of pyrite, Au-As, Zn-Bi-Te zones associated with $\mathrm{Cu}-\mathrm{Au}$ skarns; evidence for the Big Gossan and Wanagone gold deposits, Ertsberg District, Papua, Indonesia. Economic Geology (100 ${ }^{\text {th }}$ Anniversary Volume), 1021-1050. https://doi.org/10.2113/gsecongeo.100.5.1021

Ressel, M.W., Henry, C.D., 2006, Igneous geology of the Carlin Trend, Nevada: Development of the Eocene plutonic complex and significance for Carlin type gold deposits. Economic Geology, 101: 347-383. https://doi.org/10.2113/gsecongeo.101.2.347

Reyes, M., 1991, The Andacollo strata-bound gold deposit, Chile, and its position in a porphyry copper-gold system. Economic Geology, 86 (6): 1301-1316. https://doi.org/10.2113/gsecongeo.86.6.1301
Ryan, A.J., 1998, Ernest Henry copper-gold deposit. In Geology of Australian and PNG mineral deposits (Berkman, D.A., Mackenzie, D.H., Eds.), Australian Institute of Mining and Metallurgy, 22: 759-767.

Robert, J., Brommecker, R., Bourne, B.T., Dobak, P.J., Mc Ewan, C.J., Rowe, R.R. \& Zhou, X., 2007, Models and exploration methods for major gold deposit types, Ore Deposits and Exploration Technology. Proceedings of Exploration 07: Fifth Decennial International Conference in Mineral Exploration, 48: 691-711.

Ronacher, E., Richards, J.P., Reed, M.H., Bray, C.J., Spooner, E.T.C. \& Adams, P.D., 2004, Characteristics and evolution of the hydrothermal fluid in the north zone-high grade area, Porgera gold deposit, Papua-New Guinee. Economic Geology, 99 (5): 843-847.

https://doi.org/10.2113/gsecongeo.99.5.843

Rowen, L.C., Mars, J.C., 2003, Lithological mapping in the Mountain Pass, California area, using Advanced Spaceborne Thermal Emission and Reflection radiometer (ASTER) data. Remote Sensing Environment Revue, 84 (3): 350-366. https://doi.org/10.1016/S0034-4257(02)00127-X

Thompson, J.F.H., Sillitoe, R.H., Baker, T. \& Mortensen, J.K., 1999, Intrusion-related gold deposits associated with tungsten-tin provinces. Mineralium Deposita, 34: 323-334. https://doi.org/10.1007/s001260050207

Thompson, J.F.H., Newberry, R.J., 2000, Gold deposits related to reduced granitic intrusions. Review in Economic Geology, 13: 377-400. https://doi.org/10.5382/Rev.13.11

Tosdal M. R., Dilles, H. \& David R.C., 2009, From source to sinks in auriferous magmatic-hydrothermal porphyry and epithermal deposits. Elements, 5: 289-295.

https://doi.org/10.2113/gselements.5.5.289

Seltmann, R., Porter, T.M. \& Pirajno, F., 2014, Geodynamics and metallogeny of the Central Eurasian porphyry and related epithermal mineral systems: A review. Journal of Asian Earth Sciences, 79: 810-841.

https://doi.org/10.1016/j.jseaes.2013.03.030

Sillitoe, R.H., 2000, Enigmatic origin of giant gold feposits, Proceedings on Geology and Ore Deposits: The Great Basin and beyond, Geological Society of Nevada, p. 1-18.

Sillitoe, R.H., 2010, Porphyry copper systems. Economic Geology, 105: 3-41.

https://doi.org/10.2113/gsecongeo.105.1.3

Sillitoe, R.H., Halls, C. \& Grant, J.N., 1975, Porphyry tin deposits in Bolivia. Economic Geology, 70 (5): 913-927. https://doi.org/10.2113/gsecongeo.70.5.913

Sillitoe, R.H., Thompson, J.F.H., 1998, Intrusion related vein gold deposits: Types, tectono-magmatic setting and difficulties of distinction from orogenic gold deposits. Resource Geology, 48 (2): 237-250. https://doi.org/10.1111/j.1751-3928.1998.tb00021.x

Sillitoe, R.H., Hedenquist, J.W, 2003, Linkages between volcano-plutonic setting, ore fluid compositions and epithermal precious metals deposits. Bulletin of the Society of Economic Geologists, Special Publication 12: 193-219.

Simmons, S.F., White, N.C. \& John, D.A., 2005, Geological characteristics of epithermal precious and base metals deposits. Economic Geology (100 ${ }^{\text {th }}$ Anniversary Volume), 485-522. https://doi.org/10.5382/AV100.16 
Sinclair, W.D., 2007, Porphyry deposits. In Mineral Deposits of Canada (Goodfellow, W.D., Ed.), Geological Association of Canada, Special Publication, 5: 223-243.

Somarin, A.K., Ashley, P., 2004, Hydrothermal alteration and mineralization of the Glen-Eden Mo-W-Sn deposit: a leucogranite-related hydrothermal system, New England Orogen, NW Australia. Mineralium Deposita, 39: 282-300. https://doi.org/10.1007/s00126-003-0399-3

Vikenteva, O., Bortnikov, N., Vikentev, I.V., Groznova, E.O., Liubimtseva, G.N. \& Murzin, V.V., 2017, The Berezovsc giant intrusion related gold quartz deposit, Urals, Russia: evidence for multiple magmatic and metamorphic fluids reservoir. Ore Geology Reviews, 91: 837-863. https://doi.org/10.1016/j.oregeorev.2017.08.018

Vlad, Ș.N., 1998, Comparative Mesozoic-Cenozoic metallogeny of the Carpathians-Balkan and Southern Cordilliera orogens. Studia UBB Geologia, XLIII (1): 15-42.

Vlad, Ș.N., Berza, T. , 2003, Banatitic Magmatic and metallogenetic belt: Metallogeny of Carpathians segment. Studia UBB Geologia, XLVIII (1): 113-122. https://doi.org/10.5038/1937-8602.48.1.10

Vlad, Ș.N., Orlandea, E., 2004, Metallogeny of Gold Quadrilater; Style and characteristics of gold bearing epithermal-subvolcanic mineralized structures, South Apuseni Mts., Romania. Studia UBB Geologia, XLIX (1): 15-31. https://doi.org/10.5038/1937-8602.49.1.2
Wall, V.J., Graupner, T., Yantsen, V., Seltman, R. \& Hall, G.C., 2004, Muruntau, Uzbekistan: a giant thermal aureole gold system. In Predictive mineral discovery under cover (Muhling et al., Eds.), University of Western Australia, 33: 199-203.

Wallance, P.J., Edmonds, M., 2011, The sulfur budget in magmas: evidence from melt inclusions, submarine glasses and volcanic gas emissions. Reviews in Mineralogy and Geochemistry, 73 (1): 215-246. https://doi.org/10.2138/rmg.2011.73.8

Wanhainen, C., Broman, C. \& Martinsson, O., 2003, The Aitik $\mathrm{Cu}-\mathrm{Au}$ deposit in Northern Sweden: a product of high salinity fluids. Mineralium Deposita, 38: 715-726. https://doi.org/10.1007/s00126-003-0363-2

White, A.J.R., 2001, Water, restite and granite mineralization. Australian Journal of Earth Sciences, 48: 551-555. https://doi.org/10.1046/j.1440-0952.2001.00878.x

Williams, P.J., Barton, M.D., Johnson, D.A., Fontbote, L., De Haller, A., Mark, G., Oliver, N.H.S. \& Marschik, R., 2005, Iron oxides-copper-gold deposits; geology, spacetime distribution and possible models of origin. Economic Geology (100 ${ }^{\text {th }}$ Anniversary Volume), 371-406. https://doi.org/10.5382/AV100.13 